\title{
Use of ciliate communities for monitoring ecological restoration of grain for the green in north-western China
}

\author{
Hao Liu ${ }^{1,{ }^{\dagger}}$, Yingzhi Ning ${ }^{1,{ }^{*},}$ Yongqiang Yang ${ }^{2,{ }^{\dagger}}$, Huaiyin Yang ${ }^{1}$, Li Wang ${ }^{1}$, Lingyun Chen ${ }^{1,{ }^{*}}$, Yangcuo Wanma ${ }^{1}$, \\ Xiaoya Shen ${ }^{1}$
}

1 College of Life Sciences, Northwest Normal University, Lanzhou 730070, China

2 College of Grass Science, Gansu Agricultural University, Lanzhou 730070, China

\section{H I G H L I G H T S}

- To summarize the utilities of the ecological features based on community structure of the soil ciliates for assessing the ecological restoration quality in grain for green.

- Revealing the difference in the ciliate community patterns along with the ecological restoration quality of GFG.

- The soil physical-chemical variables and above-ground plants were the main factors affecting the soil ciliate community composition.

\section{ARTICLE INFO}

Article history:

Received November 23, 2020

Revised May 13, 2021

Accepted May 19, 2021

\section{Keywords:}

Soil ciliates

Grain for green

Soil physical-chemical factors

Vegetation community characteristics
GRAPHICAL ABSTRACT

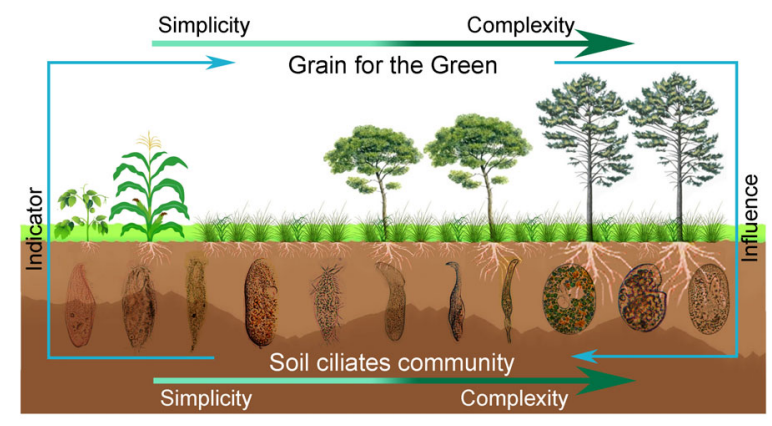

A B S T R A C T

A 1-year baseline survey was conducted in north-western China to evaluate the ecological restoration quality of grain for green (GFG) using soil ciliate communities. The aims of this study were focused on analyzing the changes of soil ciliate communities in four plots (A, GFG for 15 years; B, GFG for 13 years; C, layland; D, cultivated land) for GFG environmental assessment. Simultaneously we studied the effects of vegetation communities and physical-chemical variables with GFG changes on soil ciliates. A total of 114 species of ciliates were identified among the four sample sites, representing 9 classes, 14 orders, 22 families and 37 genera. The community patterns of the soil ciliates were significantly correlated with the individual abundance of aboveground plants, soil water content, and soil porosity. The contents of total nitrogen were the main factor affecting the soil ciliate community composition. The species number, individual abundance, and diversity index of the ciliates were each in the order $A>B>C>D$; that is, the community composition of ciliates was complicated with the implementation of the GFG. It was shown that the succession of ciliate community shifts toward promoting the complexity with the progress of GFG. These findings demonstrate that soil ciliate communities may be used as a useful indicator to evaluate the effects of the ecological restoration quality of GFG.

(c) Higher Education Press 2021

\section{Introduction}

* Corresponding authors

E-mail address: skyb514@qq.com (Y. Ning); lychen@nwnu.edu.cn (L. Chen)

†These two authors contributed equally to this work.
Grain for green (GFG) refers to projects that promote the gradual cessation of farming on cultivated land with serious problems (e.g., soil erosion, desertification, and high salinity) and the introduction of plants that are suitable for the local 
environment to improve its ecology (Li et al., 2020). Previous studies on GFG have mainly focused on vegetation, soil properties, and community patterns of soil bacteria, fungi, and invertebrates (Ouyang, 2010; Yang et al., 2010; Sabais et al., 2011; Chang et al., 2012; Piché and Kelting, 2015; Feng et al., 2019; Hao et al., 2020). Protists are valuable tools for biomonitoring studies in terrestrial ecosystems. They are sensitive to farming systems and contribute significantly to mineralization processes and key ecosystem functions in soil (Heger et al., 2012; Domonell et al., 2013). Changes in soil ciliate community structure have also been suggested as bioindicators of environmental stress, improvements in soil quality, $\mathrm{CO}_{2}$ flux increments in soil, and peat-bog restoration (Lüftenegger et al.,1985; Yeates et al., 1991; Foissner, 1999; Mayzlish and Steiberger, 2004; Mieczan et al., 2017; Gabilondo et al., 2018; Abraham et al., 2019). Several previous studies on the diversity of soil ciliate communities at GFG sites in north-western China have been carried out by Ning et al. (2011b, 2016, 2017a, 2018, 2019).

Because of their abundance, bacteria, fungi, and protists play important roles in nutrient cycling and energy flow in soils (Zhou et al., 2012; Schulz-Bohm et al., 2016; Xiong et al., 2018; Fiore-Donno et al., 2019; Liu et al., 2019; Shen, 1999; Song et al., 1999; Chen et al., 2020; Liu et al., 2020). Traditionally studies of soil ciliates focused mainly on their morphology, assemblage, ecology, and use in toxicology, but in recent years increasing emphasis is placed on molecular phylogeny, relationships with other microorganisms, and the effects of environmental pollution on soil ciliate community structure. (Liu et al., 2008; Buonanno and Ortenzi, 2010; Ning et al., 2011a; Shao et al., 2014a, 2014b; Geisen et al., 2016;
Lin et al., 2017; Luo et al., 2017; Kosiba et al., 2019; Wanner et al., 2020).

In this study, spatial variations in community patterns of soil ciliates and their potential utility as a bioindicator of environmental restoration resulting from a GFG project at a site in north-western China were studied during 1 year. The main objectives of the study were: (1) to document the community patterns of the soil ciliates; (2) to reveal differences in ciliate community patterns along with the ecological restoration quality of GFG; and (3) to summarize the utilities of the ecological features based on the community structure of the soil ciliates for assessing the ecological restoration in GFG.

\section{Materials and methods}

\subsection{Sampling sites}

The four sampling sites were located in Gulang County, northwestern China (Fig. 1), east of the Hexi Corridor $\left(37^{\circ} 09^{\prime}-\right.$ $\left.37^{\circ} 54^{\prime} \mathrm{N}, 102^{\circ} 38^{\prime}-103^{\circ} 54^{\prime} \mathrm{E}\right)$. The climate was temperate continental arid with an average annual precipitation of $300 \mathrm{~mm}$ and an annual average temperature of $4.9^{\circ} \mathrm{C}$. The soil type was Castanozems. The vegetation in the sample area was dominated by Stipa krylovii, Populus davidiana, Picea asperata, and Rosa xanthina. The vegetation coverage and other characteristic parameters are shown in Table 1.

\subsection{Experiment design and data collection}

Four sampling sites were selected. Sites A and B had 15 and
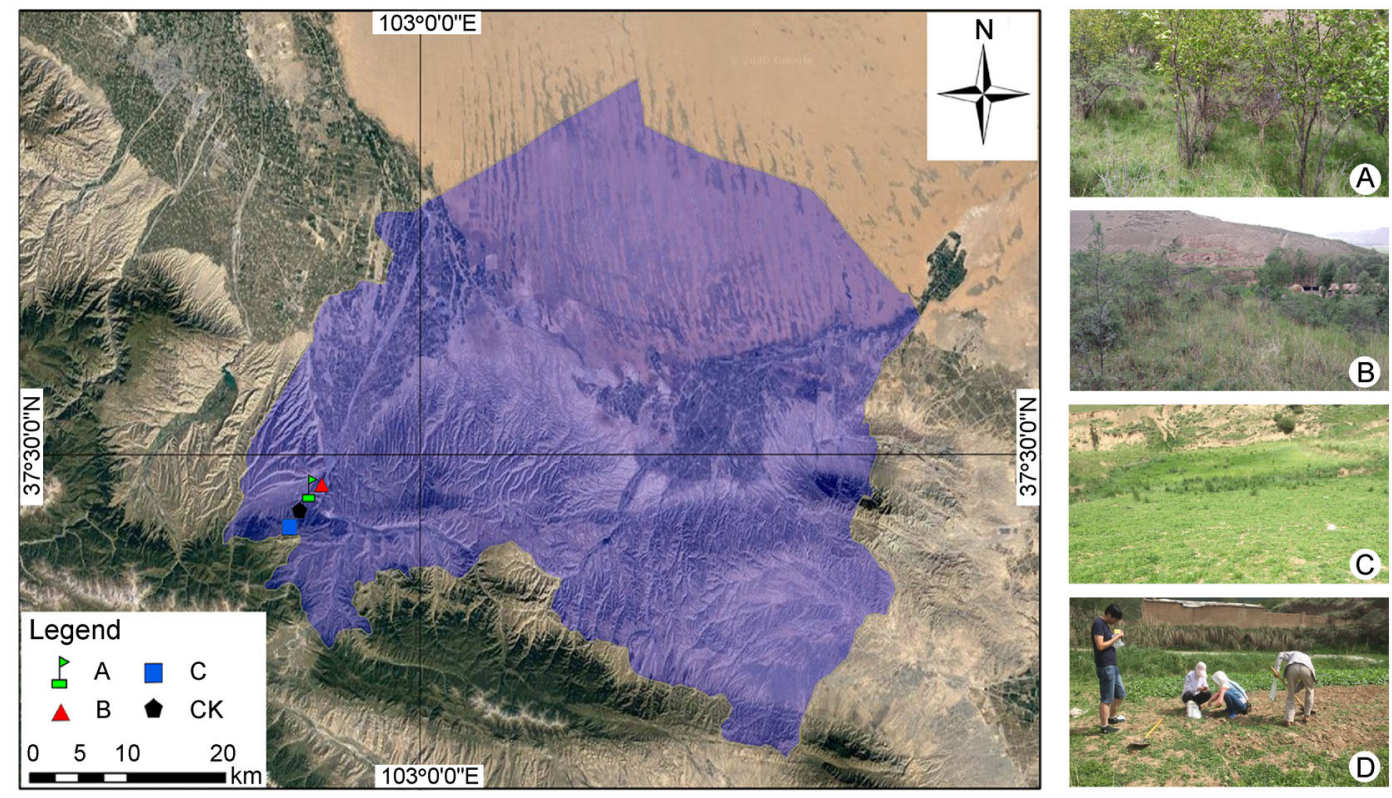

Fig. 1 Four sampling sites were investigated in Gulang County, northwestern China. A, site A: GFG for 15 years; B, site B: GFG for 13 years; both $A$ and $B$ are in mixed forests planted with Armeniaca sibirica and Hippophae rhamnoides; $C$, site $C$ : layland; $D$, site D: cultivated land. 
Table 1 Parameters of plant community at sites A and B.

\begin{tabular}{lll}
\hline Parameter of plant community & A & B \\
\hline Species number & 33.000 & 22.000 \\
Density & 98.240 & 69.280 \\
Coverage & 53.000 & 46.000 \\
Shannon-wiener index & 2.278 & 1.984 \\
Pielou index & 0.652 & 0.642 \\
Simpson index & 0.159 & 0.186 \\
Margalef index & 4.111 & 2.816 \\
\hline
\end{tabular}

13 years of GFG, respectively, and dominant plants in the two sites were Armeniaca sibirica and Hippophae rhamnoides. Site $\mathrm{C}$ was an area of layland transitioning to becoming forested after being formerly cultivated, where the dominant plants were Capsella bursa-pastoris and Potentilla anserina. Site $D$ was in an area of cultivated land planted with Brassica napus. We placed a $10 \mathrm{~m} \times 10 \mathrm{~m}$ quadrat at sites $A$ and $B$ to investigate the types and numbers of trees and shrubs and a $1 \mathrm{~m} \times 1 \mathrm{~m}$ quadrat to investigate the number of herbaceous plants. According to Flora Reipublicae Popularis Sinicae (1993) and Flora Tsinlingensis (1976), all plant species were identified. After removing branches and fallen leaves from the soil surface, we used the "plum blossom five-point sampling method" for collecting soil samples from the upper $5 \mathrm{~cm}$ layer. Additional soil samples were collected using a cutting ring with a volume of $100 \mathrm{~cm}^{3}$ for determining soil bulk density and porosity. Other data recorded were the geographical coordinates of the sampling points, soil temperature, altitude, vegetation type, and soil texture. A part of the soil sample was brought back to the laboratory to determine soil physicalchemical variables $(\mathrm{pH}$, water content, and electrical conductivity). The remaining part was naturally air-dried indoors for subsequent qualitative and quantitative experiments. During the drying process, the soil samples were covered with straw paper to prevent contamination by air-born ciliate cysts (Ning et al., 2016).

The non-flooded Petri dish method was used for the qualitative study of ciliates (Foissner, 1992). Soil (50 g) was placed in a Petri dish with a diameter of $12 \mathrm{~cm}$, and soil extract was added to make the soil samples thoroughly wet but not submerged. Two or three rice grains were added to enrich the growth of bacteria as food for the ciliates. The Petri dishes were incubated at $25^{\circ} \mathrm{C}$. Microscopic examination of the ciliates began after $24 \mathrm{~h}$ of cultivation. Ciliates were observed in vivo and by protargol staining. Species were identified using published guides and keys (Shen et al., 1990; Foissner, 1993, 1998; Ning and Shen, 1998a, 1998b; Berger, 1999, 2011; Adl et al., 2019).

According to Ning et al. (2019), the directing-culture counting method was used for the quantitative study of ciliates. Briefly, $30 \mathrm{~g}$ soil samples were added to a Petri dish with a diameter of $5 \mathrm{~cm}$. Soil extract $(30 \mathrm{~mL})$ was added, and the level of the liquid in the Petri dish was marked. The Petri dish was placed in a $25^{\circ} \mathrm{C}$ incubator, and soil extract was added every day to maintain the liquid level in the dish. All the soil suspension was removed from the Petri dish after 5, 7, 9 and 11 days and the volume of liquid was determined with a measuring tube. Five drops of suspension were placed on a glass slide using a pipette and observed under a microscope. The ciliates in each drop were enumerated, and the number of individuals per $\mathrm{mL}$ of suspension (based on 22 drops having a volume of about $1 \mathrm{~mL}$ ). From these data, the total number of ciliate cells in $30 \mathrm{~g}$ soil was calculated.

Soil $\mathrm{pH}$ was measured with a potentiometric method, used extraction method to determining soil electrical conductivity. Soil temperature was measured directly using a curved tube thermometer. Water content was determined following the method of Davidson et al. (1998). Soil porosity was determined by the soil cutting ring method (Vogel and Roth, 2001). Soil organic matter content was determined by the potassium dichromate titrimetric method. Soil total nitrogen, total potassium, and total phosphorus were determined by the Kjeldahl method, flame spectrophotometry, and sodium hydroxide alkali fusion-molybdenum-antimony colorimetric method, respectively (Bremner., 1960; Jackson., 1973; Xue et al., 2004).

\subsection{Data analysis}

The number of species at the order level was defined as dominant species, and the number of secondary species was defined as inferior dominant species. Species that were observed only once were defined as endemic species; ubiquitous species are defined as those present at each sampling site (Ning and Shen, 1998a, 1998b). One-way ANOVA and the least significant difference (LSD) were used to analyze the correlations between physical-chemical variables and ciliates. The characteristic community parameters of soil ciliates and vegetation were analyzed by cluster and multidimensional scale (MDS) analyses. Data was analyzed by SPSS 19.0, Primer 6.0 (for cluster), MDS and PCA. Histograms was made by Origin 8.0. Arcview Gis 10.6 was used for sample plotting.

\section{Results}

\subsection{Vegetation community characteristics}

A total of 4134 plants representing 42 species were observed at sites $A$ and $B$. This comprised four species (127 individuals) of woody plants and 38 species (4007 individuals) of herbaceous plants. At site A, 33 plant species were recorded, and the dominant species was Poa sphondylodes. At site B, 22 plant species were recorded, and the dominant species was Roegneria kamoji. It can be seen that with the increase of the years of GFG, species number, individual abundance, coverage, Shannon-Wiener index, Pielou index, and Margalef 
index of vegetation community were all higher at site $A$ than at site $B$, whereas the Simpson index was higher at site $B$ than at site $A$ (Table 1). That is, the vegetation structure of site $A$ was more complex than site $B$.

\subsection{Soil physical-chemical variables}

The soil physical-chemical variables of each sample are shown in Fig. 2. Values for soil porosity, organic matter, water content, and total nitrogen were all higher in the soils at sites $A$ and $B$ than at sites $C$ and $D(P<0.05)$, and were in the following order: $A>B>C>D$. Values of $p H$, conductivity, total phosphorus, and total nitrogen were significantly higher in soil from cultivated land (site D) than at sites where GFG had been implemented for 13 years or more (sites $A$ and $B)(P<0.05)$, and were in the following order: $D>C>B>A$. Soil temperature did not differ significantly among the four sites $(P>0.05)$.

\subsection{Composition of soil ciliate community}

The dominant group was Sporadotrichida, with 35 species, accounting for $30.7 \%$ of the soil ciliate species richness. The secondary dominant group was Haptorida, with 21 species accounting for $18.42 \%$ of soil ciliate species richness (Table 2).

The dominant groups of soil ciliates in various samples underwent obvious succession. Species of Sporadotrichida were dominant at sites $A$ and $B$, whereas species of Colpodida were dominant at site $D$ (Fig. 3). It can be seen that the number of soil ciliate species increased, the community structure tended to be more complex.

\subsection{Distribution of soil ciliates}

A total of 114 species of soil ciliates were identified at the four sampling sites. At site A, 91 species were identified, representing 33 genera, 20 families, 13 orders, and nine classes, accounting for $79.82 \%$ of the total species number. 87 species were identified at site $B$, representing 31 genera, 19 families, 14 orders, and nine classes, accounting for $76.32 \%$ of the total species number. At site $C, 74$ species were identified, representing 28 genera, 17 families, 11 orders, and eight classes, accounting for $64.91 \%$ of the total species number. At site D, 55 species were identified, representing 23 genera, 15 families, 10 orders, and eight classes, accounting for $48.25 \%$ of the total species number.

The results of the analyses are shown in Fig. 4. In the cluster analysis, sites $A$ and $B$ clustered together, and then clustered with $C$, whereas site D clustered with sites $A, B$ and $C$ sample at the furthest distance. The results of MDS analysis are consistent with the clustering analysis; that is, sites $A, B$, and $C$ are close to each other, and site $D$ is the most isolated. Through clustering and MDS analyses, it is shown that sites $A$ and $B$ have a closer similarity with site $C$ than with site $D$.
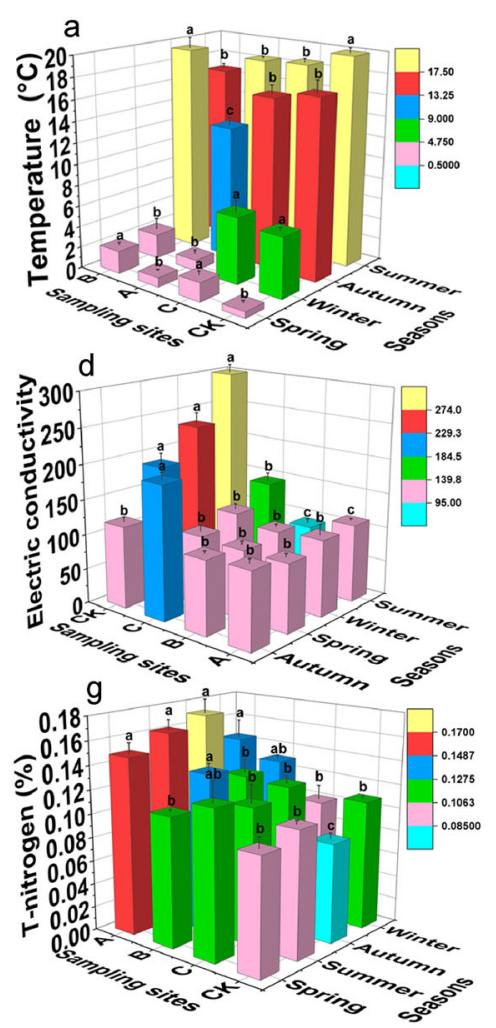
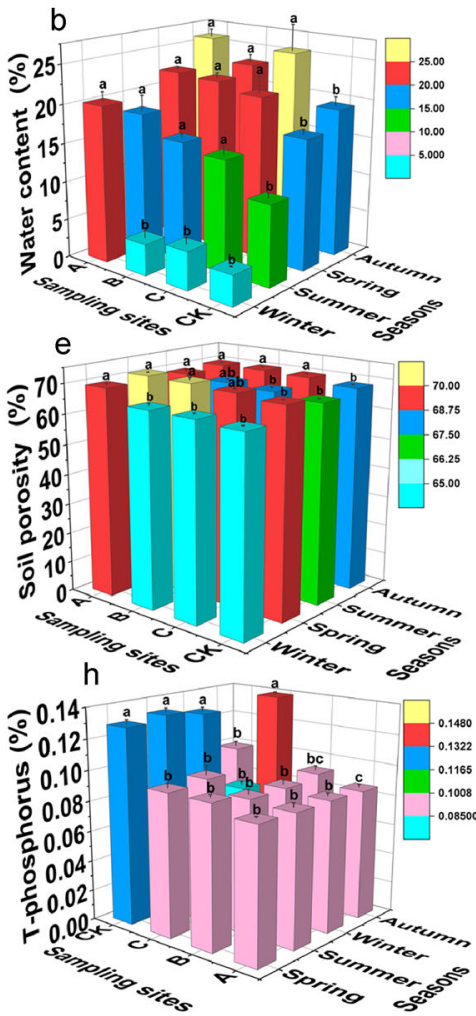

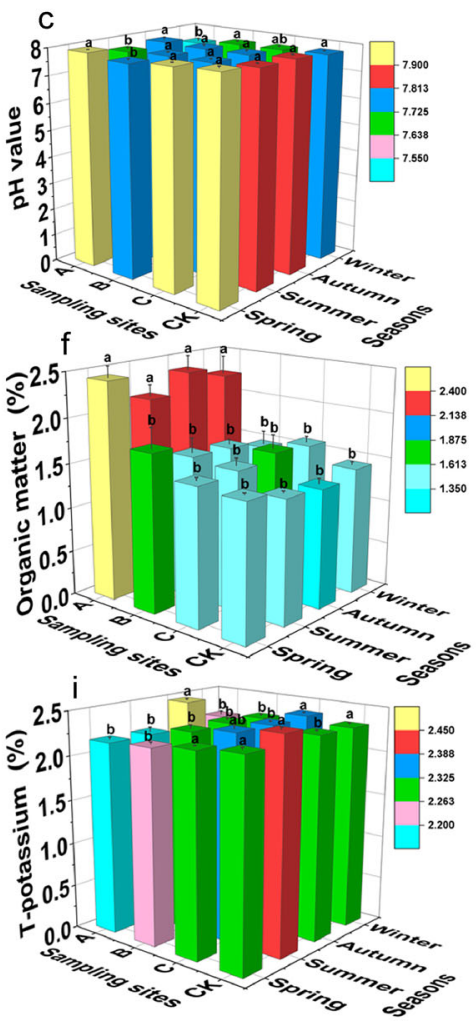

Fig. 2 The sol physical-chemical variables (a: Temperature; b: Water content; c: pH value; d: Conductivity; e: Soil porosity; f: Organic matter; g: Total nitrogen; h: Total phosphorus; i: Total potassium) in each season (spring, summer, autumn, winter) and each sampling site (A, B, C, D). 
Table 2 Community composition of soil ciliates in various sampling sites.

\begin{tabular}{|c|c|c|c|c|c|}
\hline Phylum & Class & Order & Family & Genus & Species \\
\hline & Heterotrichea & Heterotrichida & 1 & 1 & 1 \\
\hline & Spirotrichea & Euplotida & 1 & 1 & 1 \\
\hline & & Stichotrichida & 3 & 4 & 6 \\
\hline & & Sporadotrichida & 2 & 9 & 35 \\
\hline & & Urostylida & 1 & 5 & 14 \\
\hline & Armophorea & Armophorida & 1 & 1 & 3 \\
\hline \multirow[t]{8}{*}{ Ciliophora } & Litostomatea & Haptorida & 4 & 6 & 21 \\
\hline & Nassophorea & Nassulida & 1 & 1 & 4 \\
\hline & & Microthoracida & 1 & 2 & 3 \\
\hline & Colpodea & Colpodida & 1 & 1 & 14 \\
\hline & & Cyrtolophosidida & 1 & 1 & 1 \\
\hline & Prostomatea & Prorodontida & 2 & 2 & 4 \\
\hline & Oligohymenophorea & Pleuronematida & 2 & 2 & 4 \\
\hline & Phyllopharyngea & Chlamydodontida & 1 & 1 & 3 \\
\hline Total & 9 & 14 & 22 & 37 & 114 \\
\hline
\end{tabular}

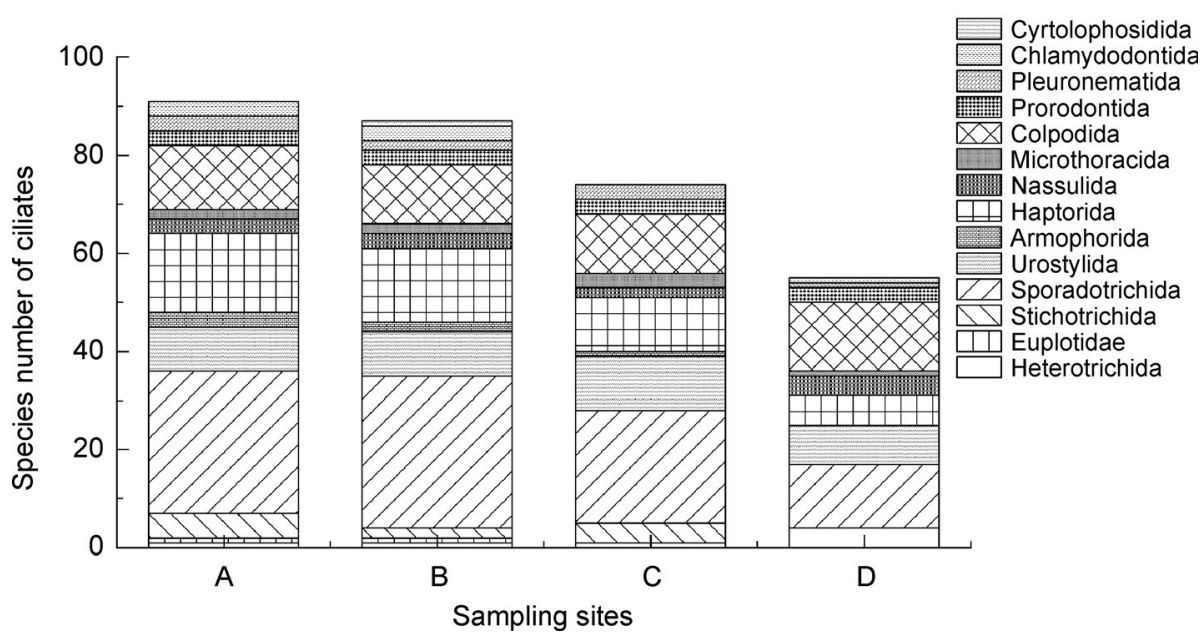

Fig. 3 Community composition of soil ciliates at the four sampling sites.

\subsection{Ubiquitous and endemic species}

Ubiquitous species are defined as those present at each sampling site. Among the total of 114 ciliate species recorded, 30 were ubiquitous, accounting for $26.32 \%$ of total ciliate species richness. These were primarily composed of colpodids, stichotrichids, sporadotrichids, and urostylids. Endemic species were defined as those that appeared only at one sample site. There were 10 endemic species at both sites $A$ and $B$, accounting for $8.77 \%$ of ciliate species. It includes omnivorous ciliates such as sporadotrichids, haptorids, and stichotrichids. There were two endemic species at site $\mathrm{C}$, accounting for $1.75 \%$ of the total species, one urostylid and one prorostomatid. There was one endemic species at site $D$, accounting for $0.88 \%$ of the total species. It can be seen that the dominant of ciliate species at the four sites was in the order: $\mathrm{D}>\mathrm{C}>\mathrm{B}>\mathrm{A}$.

\subsection{Community parameters of soil ciliates}

The species number, individual abundance, and C/P index of soil ciliates at each sampling site are shown in Table 3. In any given season, the number of ciliate species at the four sites was in the order: $A>B>C>D$, and the individual abundance of ciliates at sites $A$ and $B$ was significantly larger than at sites $C$ and $\mathrm{D}(P<0.05)$. The individual abundance of ciliates in any 

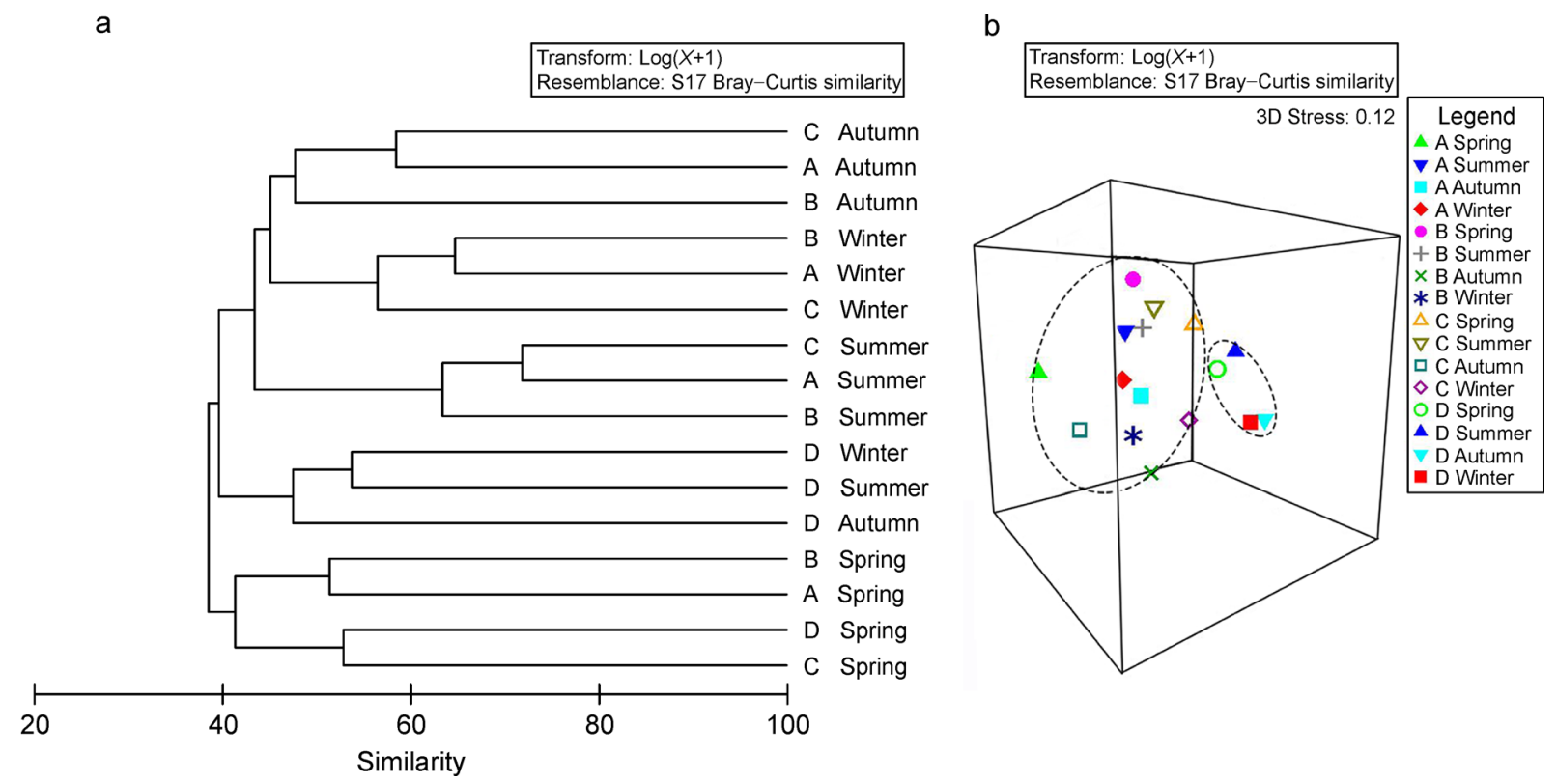

Fig. 4 Cluster analysis (a) and MDS (b) analysis on species distribution of soil ciliates at the four sampling sites.

Table 3 Species number, individual abundance and C/P index of soil ciliates in each season (spring, summer, autumn, winter) and at each sampling site (A, B, C, D).

\begin{tabular}{|c|c|c|c|c|}
\hline Sampling sites & Seasons & Species number & Individual abundance & $\mathrm{C} / \mathrm{P}$ index \\
\hline$A$ & Spring & 41 & $72.51 \pm 0.26 c$ & 0.32 \\
\hline B & & 37 & $57.43 \pm 0.26 \mathrm{c}$ & 0.35 \\
\hline $\mathrm{C}$ & & 29 & $48.52 \pm 0.28 \mathrm{c}$ & 0.44 \\
\hline $\mathrm{D}$ & & 24 & $38.91 \pm 0.36 \mathrm{c}$ & 0.73 \\
\hline A & Summer & 46 & $80.28 \pm 0.45 b$ & 0.31 \\
\hline B & & 33 & $68.37 \pm 0.71 \mathrm{~b}$ & 0.35 \\
\hline $\mathrm{C}$ & & 32 & $59.26 \pm 0.69 \mathrm{~b}$ & 0.37 \\
\hline $\mathrm{D}$ & & 21 & $48.56 \pm 0.51 \mathrm{~b}$ & 0.7 \\
\hline A & Autumn & 50 & $110.61 \pm 0.84 a$ & 0.32 \\
\hline B & & 41 & $96.89 \pm 1.06 \mathrm{a}$ & 0.4 \\
\hline $\mathrm{C}$ & & 39 & $77.96 \pm 0.54 \mathrm{a}$ & 0.37 \\
\hline $\mathrm{D}$ & & 28 & $60.01 \pm 0.57 a$ & 0.69 \\
\hline A & Winter & 36 & $57.55 \pm 0.88 d$ & 0.43 \\
\hline $\mathrm{B}$ & & 32 & $48.24 \pm 0.65 d$ & 0.45 \\
\hline C & & 28 & $38.76 \pm 0.39 d$ & 0.5 \\
\hline $\mathrm{D}$ & & 20 & $28.59 \pm 0.43 \mathrm{~d}$ & 0.8 \\
\hline
\end{tabular}

Note: The data were means \pm standard error (SE); different lowercase letters mean significant difference at 0.05 level $(n=3)$.

given season was in the order: $A>B>C>D$, and the total ciliate abundance among the four seasons was in the order autumn>summer>spring > winter. The $\mathrm{C} / \mathrm{P}$ index of soil ciliates was the reverse of species number and abundance, i.e., the $\mathrm{C} / \mathrm{P}$ index was in the order $\mathrm{D}>\mathrm{C}>\mathrm{B}>\mathrm{A}$. The number of soil ciliate species and their individual abundance in the soils after GFG (sites $A$ and $B$ ) were higher than at sites $C$ and $D$, whereas the C/P index was the opposite.

The soil ciliate community indices at each of the four sites are shown in Table 4. For each season, the values of the 
Table 4 Shannon-Wiener diversity index, Margalef richness index, Pielou evenness index and Simpson dominance index of soil ciliates in each season (spring, summer, autumn, winter) and at each sampling soie (A, B, C, D).

\begin{tabular}{|c|c|c|c|c|c|}
\hline Sampling sites & Seasons & $\begin{array}{l}\text { Shannon-Wiener } \\
\text { diversity index }\end{array}$ & $\begin{array}{l}\text { Margalef richness } \\
\text { index }\end{array}$ & $\begin{array}{l}\text { Pielou evenness } \\
\text { index }\end{array}$ & $\begin{array}{l}\text { Simpson dominance } \\
\text { index }\end{array}$ \\
\hline$A$ & Spring & $2.290 \pm 0.011 \mathrm{a}$ & $2.849 \pm 0.039 a$ & $0.889 \pm 0.005 b$ & $0.281 \pm 0.014 a$ \\
\hline B & & $2.052 \pm 0.016 \mathrm{~b}$ & $2.071 \pm 0.024 \mathrm{~b}$ & $0.916 \pm 0.006 a b$ & $0.159 \pm 0.005 b$ \\
\hline C & & $1.807 \pm 0.012 \mathrm{c}$ & $1.479 \pm 0.023 c$ & $0.944 \pm 0.003 a$ & $0.196 \pm 0.004 a$ \\
\hline $\mathrm{D}$ & & $1.695 \pm 0.007 \mathrm{~d}$ & $1.363 \pm 0.003 \mathrm{c}$ & $0.946 \pm 0.004 a$ & $0.198 \pm 0.007 \mathrm{~b}$ \\
\hline$A$ & Summer & $2.250 \pm 0.018 a$ & $2.965 \pm 0.035 a$ & $0.853 \pm 0.004 \mathrm{c}$ & $0.140 \pm 0.005 a$ \\
\hline B & & $2.084 \pm 0.011 \mathrm{~b}$ & $2.178 \pm 0.038 b$ & $0.899 \pm 0.004 \mathrm{~b}$ & $0.147 \pm 0.003 b$ \\
\hline $\mathrm{C}$ & & $1.879 \pm 0.011 \mathrm{c}$ & $1.567 \pm 0.023 c$ & $0.940 \pm 0.004 \mathrm{a}$ & $0.168 \pm 0.003 b$ \\
\hline $\mathrm{D}$ & & $1.804 \pm 0.017 \mathrm{c}$ & $1.499 \pm 0.019 c$ & $0.942 \pm 0.003 a$ & $0.172 \pm 0.010 \mathrm{c}$ \\
\hline$A$ & Autumn & $2.673 \pm 0.016 a$ & $4.041 \pm 0.026 a$ & $0.892 \pm 0.004 a$ & $0.093 \pm 0.010 a$ \\
\hline B & & $2.480 \pm 0.012 b$ & $3.321 \pm 0.037 \mathrm{~b}$ & $0.891 \pm 0.005 a$ & $0.110 \pm 0.005 \mathrm{c}$ \\
\hline C & & $2.222 \pm 0.025 \mathrm{c}$ & $2.617 \pm 0.050 \mathrm{c}$ & $0.884 \pm 0.006 a$ & $0.127 \pm 0.004 \mathrm{c}$ \\
\hline $\mathrm{D}$ & & $1.918 \pm 0.011 \mathrm{~d}$ & $1.809 \pm 0.047 \mathrm{~d}$ & $0.904 \pm 0.006 a$ & $0.170 \pm 0.006 \mathrm{c}$ \\
\hline$A$ & Winter & $1.908 \pm 0.023 a$ & $1.879 \pm 0.070 \mathrm{a}$ & $0.891 \pm 0.002 b$ & $0.178 \pm 0.005 a$ \\
\hline B & & $1.749 \pm 0.018 b$ & $1.549 \pm 0.038 a$ & $0.901 \pm 0.008 b$ & $0.197 \pm 0.004 \mathrm{a}$ \\
\hline C & & $1.628 \pm 0.014 \mathrm{c}$ & $1.259 \pm 0.033 b$ & $0.948 \pm 0.004 a$ & $0.211 \pm 0.003 a$ \\
\hline $\mathrm{D}$ & & $1.464 \pm 0.021 \mathrm{~d}$ & $1.185 \pm 0.032 b$ & $0.910 \pm 0.014 \mathrm{~b}$ & $0.242 \pm 0.007 \mathrm{a}$ \\
\hline
\end{tabular}

Note: The data were means \pm standard error (SE), different lowercase letters mean significant difference at 0.05 level $(n=3)$.

species diversity and richness indices at sites $A$ and $B$ were significantly higher than those at sites $C$ and $D(P<0.05)$. These indices were in the order: $A>B>C>D$.

3.7 Relationship between soil ciliates and soil physical-chemical variables

As shown in Table 5, for temperature, the most significant negative correlation was with the dominance index $(P<0.01)$.
For water content, the most significant positive correlation was with species diversity $(P<0.01)$. For soil porosity, the most significant positive correlations were with species number and diversity $(P<0.01)$. For total nitrogen, the most significant positive correlations were with species number, individual abundance, diversity, and richness $(P<0.01)$, and the most significant negative correlation was with species evenness $(P<0.01)$. For organic matter, the most significant positive correlations were with species number and richness

Table 5 Relationships between the community patterns of soil ciliates and the soil physical-chemical variables (Pearson's correlation coefficient).

\begin{tabular}{|c|c|c|c|c|c|c|}
\hline $\begin{array}{l}\text { Physical-chemical } \\
\text { variables }\end{array}$ & $\begin{array}{l}\text { Species } \\
\text { number }\end{array}$ & $\begin{array}{l}\text { Individual } \\
\text { abundance }\end{array}$ & $\begin{array}{l}\text { Diversity } \\
\text { index }\end{array}$ & $\begin{array}{l}\text { Evenness } \\
\text { index }\end{array}$ & $\begin{array}{l}\text { Dominance } \\
\text { index }\end{array}$ & $\begin{array}{l}\text { Richness } \\
\text { index }\end{array}$ \\
\hline Temperature $\left({ }^{\circ} \mathrm{C}\right)$ & 0.168 & 0.472 & 0.379 & -0.235 & $-0.631^{* *}$ & 0.340 \\
\hline Water content (\%) & $0.584^{*}$ & $0.558^{*}$ & $0.651^{* *}$ & -0.264 & -0.267 & $0.560^{*}$ \\
\hline Soil porosity (\%) & $0.628^{* *}$ & $0.608^{*}$ & $0.697^{* *}$ & -0.335 & -0.310 & $0.605^{*}$ \\
\hline T-nitrogen $\left(\mathrm{g} \mathrm{Kg}^{-1}\right)$ & $0.807^{* *}$ & $0.671^{* *}$ & $0.676^{* *}$ & $-0.670^{* *}$ & -0.261 & $0.731^{* *}$ \\
\hline $\mathrm{T}$-potassium $\left(\mathrm{g} \mathrm{Kg}^{-1}\right)$ & -0.205 & 0.102 & 0.011 & 0.428 & -0.369 & 0.018 \\
\hline T-phosphorus $\left(\mathrm{g} \mathrm{Kg}^{-1}\right)$ & $-0.524^{*}$ & -0.336 & -0.331 & 0.246 & 0.063 & -0.315 \\
\hline Organic matter $\left(\mathrm{g} \mathrm{Kg}^{-1}\right)$ & $0.770^{* *}$ & $0.564^{*}$ & $0.621^{*}$ & $-0.567^{*}$ & -0.033 & $0.665^{\star *}$ \\
\hline $\mathrm{pH}$ value & -0.265 & -0.082 & -0.008 & 0.418 & 0.219 & -0.056 \\
\hline Electric conductivity $(\mu S)$ & $-0.604^{*}$ & -0.394 & -0.412 & 0.343 & 0.122 & -0.376 \\
\hline
\end{tabular}

* Represents the correlation at the 0.05 level, ${ }^{* *}$ Represents the correlation at the 0.01 level, - Represents negative correlation. 
$(P<0.01)$. Therefore, water content, soil porosity, total nitrogen, and organic matter were the key soil physical and chemical variables affecting the soil ciliate communities.

The results of principal component analysis of soil ciliate community parameters and soil physical-chemical variables are shown in Fig. 5. Nine physical-chemical variables were measured: temperature $(T)$, water content (WC), soil porosity $(\mathrm{SP})$, total nitrogen (TN), total potassium (TK), total phosphorus (TP), organic matter (OM), electrical conductivity (SC), and $\mathrm{pH}$. Six ciliate community parameters were included in the analysis: species number (SN), individual abundance (D), diversity index $\left(\mathrm{H}^{\prime}\right)$, evenness index $(\mathrm{E})$, dominance index $(\mathrm{C})$ and richness index (M). As can be seen from the figure, the line segments of vectors for WC, SP, OM, TN, SN, D, H' and M were relatively long and the angles between them were relatively small, indicating significant correlations among these factors. The angles between the vectors of other factors were greater than 90 degrees, indicating no significant correlations among them. Therefore, water content, soil porosity, organic matter, and total nitrogen were the main soil physical-chemical variables that affected the soil ciliate communities, which was consistent with Pearson correlation analysis.

\subsection{Relationship between soil ciliates and vegetation parameters}

The results of cluster and MDS analysis of the community patterns of soil ciliates and vegetation community characteristic parameters at the four sampling sites are shown in Fig. 6. In the cluster analysis, the species number and individual abundance of soil ciliates were highly correlated with vegetation coverage, species number of vegetation, and individual abundance of vegetation. Soil ciliate species richness, diversity, and evenness had high correlations with vegetation richness, diversity, and evenness. Soil ciliate dominance index and vegetation community dominance index had poor correlations with other indices. The results of the MDS analysis were consistent with the clustering analysis.

\section{Discussion}

\subsection{Effects of different patterns of GFG on vegetation communities}

GFG is one of the most important measures to restore vegetation and improve ecology. The indexes used by domestic scholars to study vegetation diversity include those of species richness, diversity, evenness, and dominance (Wan et al., 2014). It is essential to analyze plant community species diversity and reveal community succession and stability (Kai and Jaanus, 1999; Burton and Mark, 2001). In this study, the measures of coverage, number of species and individual abundance, diversity, richness, and evenness of the plant community were higher for site $A$ than for site $B$, while the dominance index was the opposite. These findings reflect the greater number of years of GFG at site $A$ (15 years) than at site B (13 years). The effects of GFG on plant species abundance and community composition are mainly caused by enhanced deciduous vegetation layers, root systems and nitrogen fixation. With increasing stocks of leaf litter in forests, the storage of $\mathrm{C}$ and $\mathrm{N}$ in soil increases, and soil's physical properties are improved (Zhang et al., 2011; Shang et al., 2015; Liu et al., 2020).

4.2 Effects of GFG on soil physical and chemical variables under different return modes

With the conversion of habitats by GFG, the community structure of above-ground vegetation tends to be stable, and the soil condition is improved. In this study, soil physical and
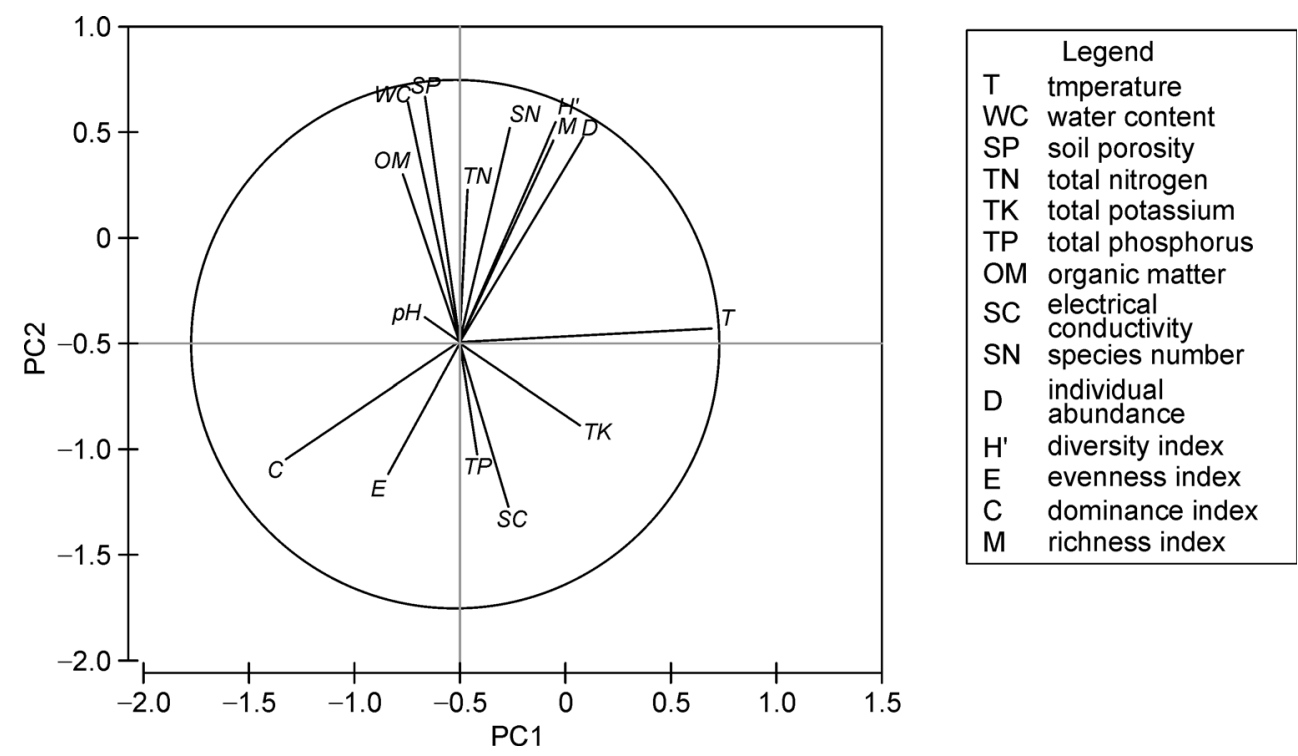

Fig. 5 The PCA analysis between the community characteristic parameters of soil ciliates and soil environmental variables. 
a

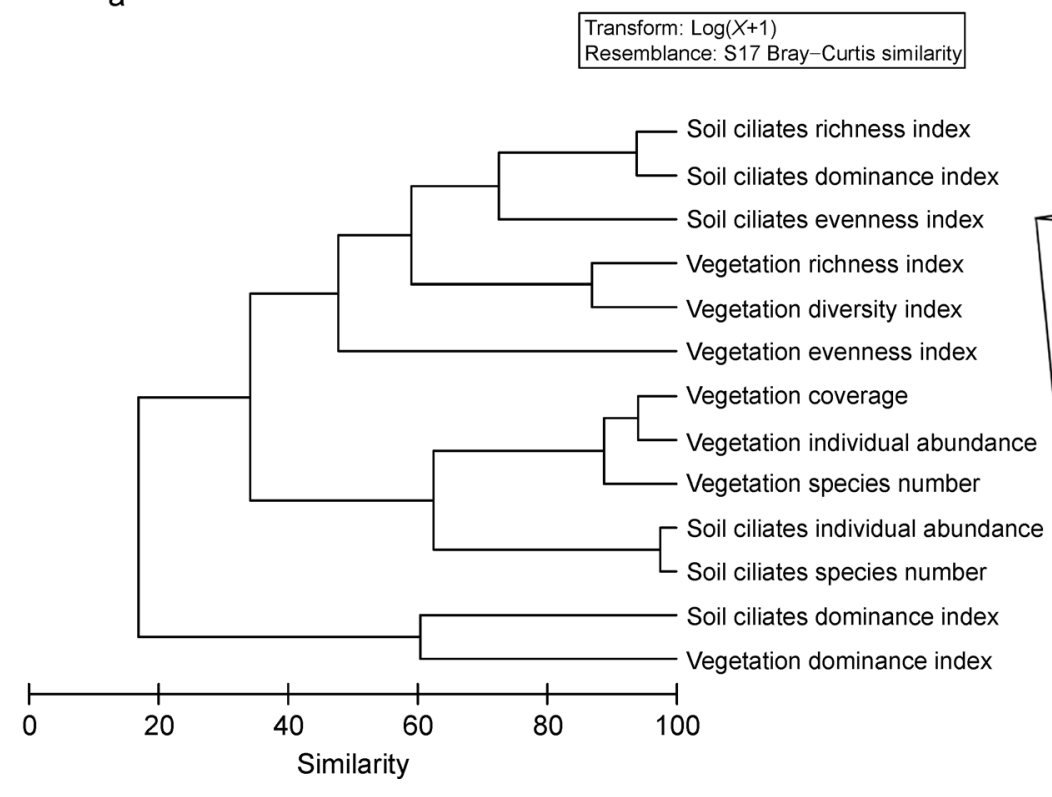

b

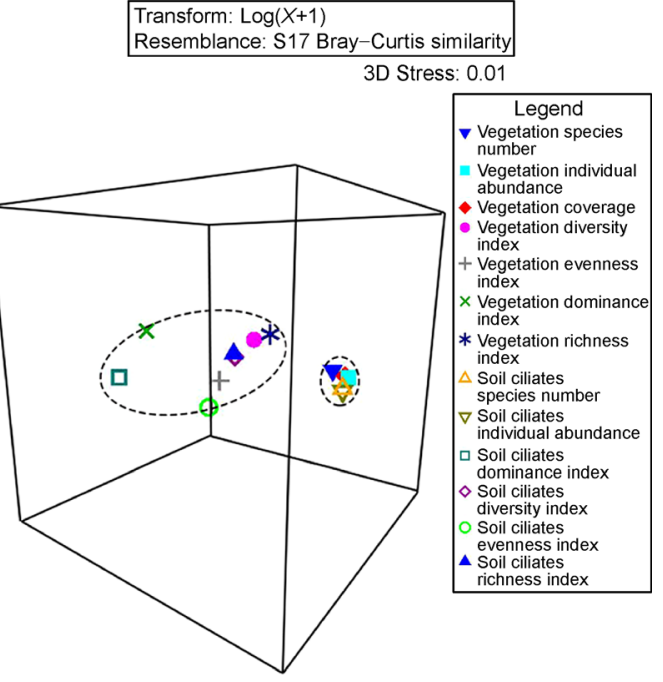

Fig. 6 The cluster (a) and MDS (b) analysis on soil ciliates and plant community at the four sampling sites.

chemical variables, such as soil water content, soil porosity, organic matter, and total nitrogen, were significantly higher where GFG has been implemented (sites $A$ and $B$ ) compared to sites $\mathrm{C}$ and site $\mathrm{D}(P<0.05)$. The soil water content of site $\mathrm{A}$ was $70.92 \%$ higher than site $D$, mainly because with the progress of GFG and the increase of aboveground vegetation, there were increases in the surface litter, humus, and soil water storage capacity, and a decrease in transpiration (Zhang et al., 2018; Mo et al., 2020). Furthermore, the soil porosity of site $A$ was $4.09 \%$ higher than site $D$, at the sites where GFG had been implemented, probably due to the increased development of plant root systems. The results showed that the soil porosity of the GFG sites was significantly higher than that of the cultivated land, which is consistent with the present findings (Ning et al., 2019). Soil organic matter of site $A$ was $62.41 \%$ higher than site $D$, probably as a result of higher microbial biomass, which decomposes vegetation litter and humus on the soil surface resulting in more soil organic matter (Cui et al., 2010; Lin et al., 2011; Zhang et al., 2018). The total nitrogen content of site A was $58.59 \%$ higher than site $D$, probably as a result of nitrogen from the leaf litter entering the soil with rainwater following decomposition by microorganisms. The total nitrogen content in soil was consistent with that predicted by the vertical variation law of soil organic matter content (Pang and Bao, 2011).

4.3 Effects on soil ciliate community of GFG under different return regimes

The diversity of soil animal communities changes with different vegetation types; that is, the diversity of surface vegetation communities affects the diversity of soil animal species (Chauvat et al., 2011). Furthermore, the population dynamics of soil animals respond to the changes in vegetation and environmental restoration, so it is susceptible to external environmental factors. Therefore, the dynamic changes of soil animal communities can serve as an important bioindicator of vegetation restoration and environmental improvement (Sabais et al., 2011; Zhang et al., 2012). The findings of the present study showed that with the progress of GFG, the species number, individual abundance, diversity index, richness index, and evenness index of soil ciliate communities at each site were in the order $A>B>C>D$, while the dominance index and $C / P$ index showed the opposite. Due to its longer return time, site $A$ had the most complete vegetation community and the most stable and complex ciliate community, indicating that the soil conditions were the most suitable for the survival of soil ciliates. The C/P index at site $D$ was higher than that at sites $A$ and $B$, indicating that the soil environment of farmland is not as suitable for the survival of soil ciliates, which is consistent with previous findings (Ning et al., 2017b). Correlation analysis showed that water content, soil porosity, total nitrogen, organic matter, and soil ciliate community parameters were the most significantly positively correlated, also consistent with the findings of Zou et al. (2009). Colpodids were the dominant ciliate species at site D (cultivated land), whereas sporadtrichids were dominant in the soil at sites $A$ and $B$ (where GFG had been implemented).

\section{Conclusions}

This study shows that with the implementation of GFG, the above-ground vegetation community structure is complicated. When the physical and chemical variables of the surface soil are all significantly changed, the species number, individual 
abundance, diversity index, evenness index, richness index of soil ciliates (increases), and the dominance index (decreases) change. However, the community structure of soil ciliates remains complicated. The correlation analysis showed that water content, soil porosity, total nitrogen, and organic matter had the most influence on the characteristics of the soil ciliate community. Therefore, the community parameters of soil ciliates can be used as an evaluation index of the ecological restoration effect of GFG.

\section{Conflicts of interest}

Authors declare that they have no competing interests.

\section{Acknowledgments}

Thanks to professor Henglong Xu from Ocean University of China for revising the abstract of this article. Thanks to Alan Warren, a protozoology expert and senior researcher at the Natural History Museum, London, UK, for providing guidance on the full text. This work was supported by the National Natural Science Foundation of China (Project number: 41761056, 41361055, 42067012).

\section{References}

Abraham, J.S., Sripoorna, S., Dagar, J., Jangra, S., Kumar, A., Yadav, K., Singh, S., Goyal, A., Maurya, S., Gambhir, G., Toteja, R., Gupta, R., Singh, D.K., El-Serehy, H.A., Al-Misned, F.A., Al-Farraj, S.A., Al-Rasheid, K.A., Maodaa, S.A., Makhija, S., 2019. Soil ciliates of the Indian Delhi Region: Their community characteristics with emphasis on their ecological implications as sensitive bioindicators for soil quality. Saudi Journal of Biological Sciences 26, 1305-1313.

Adl, S.M., Bass, D., Lane, C.E., Lukes, J., Schoch, C.L., Smirnov, A., Agatha, S., Berney, C., Brown, M.W., Burki, F., Cárdenas, P., Čepička, I., Chistyakova, L., Campo, J., Dunthorn, M., Edvardsen, B., Eglit, Y., Guillou, L., Hampl, V., Heiss, A.A., Hoppenrath, M., James, T.Y., Karnkowska, A., Karpov, S., Kim, E., Kolisko, M., Kudryavtsev, A., Lahr, D.J.G., Lara, E., Le Gall, L., Lynn, D.H., Mann, D.G., Massana, R., Mitchell, E.A.D., Morrow, C., Park, J.S., Pawlowski, J.W., Powell, M.J., Richter, D.J., Rueckert, S., Shadwick, L., Shimano, S., Spiegel, F.W., Torruella, G., Youssef, N., Zlatogursky, V., Zhang, Q., 2019. Revisions to the classification, nomenclature, and diversity of eukaryotes. Journal of Eukaryotic Microbiology 66, 4-119.

Berger, H., 1999. Monograph of the Oxytrichidae (Ciliophora, Hypotrichia). Springer Netherlands.

Berger, H., 2011. Monograph of the Gonostomatidae and Kahliellidae (Ciliophora, Hypotricha). Springer Netherlands.

Bremner, J., 1960. Determination of nitrogen in soil by the Kjeldahl method. Journal of Agricultural Science 55, 11-33.

Buonanno, F., Ortenzi, C., 2010. The protozoan toxin climacostol and its derivatives: Cytotoxicity studies on 10 species of free-living ciliates. Biologia 65, 675-680.

Burton, K.L., Mark, D.E., 2001. Species diversity of bats (Mammalia:
Chiroptera) in Iwokrama forest, Guyana, and the Guianan subregion: implications for conservation. Biodiversity and Conservation 10, 613-657.

Chang, R.Y., Fu, B.J., Liu, G.H., Wang, S., Yao, X.L., 2012. The effects of afforestation on soil organic and inorganic carbon: A case study of the Loess Plateau of China. Catena 95, 145-152.

Chauvat, M., Titsch, D., Zaytsev, A.S., Wolters, V., 2011. Changes in soil faunal assemblages during conversion from pure to mixed forest stands. Forest Ecology and Management 262, 317-324.

Chen, X.Y., Xue, W.F., Xue, J.G., Griffiths, B.S., Liu, M.Q., 2020. Contribution of bacterivorous nematodes to soil resistance and resilience under copper or heat stress. Soil Ecology Letters 2, 220229.

Cui, B.S., Zhao, H., Li, X., Zhang, K.J., Ren, H.L., Bai, J.H., 2010. Temporal and spatial distributions of soil nutrients in Hani terraced paddy fields, southwestern China. Procedia Environmental Sciences 2, 1032-1042.

Davidson, E.A., Belk, E.L., Boone, R.D., 1998. Soil water content and temperature as independent or confounded factors controlling soil respiration in a temperate mixed hardwood forest. Global Change Biology 4, 217-227.

Domonell, A., Brabender, M., Nitschea, F., Bonkowski, M., Arndt, H., 2013. Community structure of cultivable protists in different grassland and forest soils of Thuringia. Pedobiologia 56, 1-7.

Editorial Committee of Chinese Flora of Chinese Academy of Sciences, 1993. Flora Reipublicae Popularis Sinicae. Beijing: Science Press.

Feng, D.R., Wang, J.M., Fu, M.C., Liu, G.C., Zhang, M., Tang, R.B., 2019. Spatiotemporal variation and influencing factors of vegetation cover in the ecologically fragile areas of China from 2000 to 2015: a case study in Shaanxi Province. Environmental Science and Pollution Research International 26, 28977-28992.

Fiore-Donno, A.M., Richter-Heitmann, T., Degrune, F., Dumack, K., Regan, K.M., Marhan, S., Boeddinghaus, R.S., Rillig, M.C., Friedrich, M.W., Kandeler, E., Bonkowski, M., 2019. Functional traits and spatio-temporal structure of a major group of soil protists (Rhizaria: Cercozoa) in a temperate grassland. Frontiers in Microbiology 10, 1332-1346.

Foissner, W., 1992. Estimating the species richness of soil protozoa using the "non-flooded Petri dish method". Netherlands Springer.

Foissner, W., 1993. Colpodea (Ciliophora). New York Dieter M.

Foissner, W., 1998. An updated compilation of world soil ciliates (Protozoa, Ciliophora), with ecological notes, new records, and descriptions of new species. European Journal of Protistology 34 , 195-235.

Foissner, W., 1999. Soil protozoa as bioindicators: pros and cons, methods, diversity, representative examples. Agriculture, Ecosystems \& Environment 74, 95-112.

Gabilondo, R., Blanco, S., Fernández-Montiel, I., García, D.A., Bécares, E., 2018. Ciliates as bioindicators of $\mathrm{CO}_{2}$ in soil. Ecological Indicators 85, 1192-1203.

Geisen, S., Koller, R., Hünninghaus, M., Dumack, K., Urich, T., Bonkowski, M., 2016. The soil food web revisited: Diverse and widespread mycophagous soil protists. Soil Biology \& Biochemistry $94,10-18$.

Hao, B.B., Cao, S.P., Li, Y., Liu, J., Qiang, D.H., Liu, C.H., 2020. 
Temporal and spatial changes of soil animals in returning farmland to forestland in different years in Wuqi County. Journal of Arid Land Resources and Environment 34, 130-136.

Heger, T.J., Straub, F., Mitchell, E.A.D., 2012. Impact of farming practices on soil diatoms and testate amoebae: A pilot study in the DOK-trial at Therwil, Switzerland. European Journal of Soil Biology 49, 31-36.

Jackson, M.L., 1973. Soil Chemical Analysis. Prentice Hall of India Pvt. Ltd.

Kai, V., Jaanus, P., 1999. Diversity of bryophyte vegetation in some forest types in Estonia: a comparison of old un-managed and managed forests. Biodiversity and Conservation 8, 1595-1620.

Kosiba, J., Wilk-Woz'niak, E., Krztoń, W., 2019. The effect of potentially toxic cyanobacteria on ciliates (Ciliophora). Hydrobiologia 827, 325-335.

Li, W.Q., Chen, J.H., Zhang, Z.M., 2020. Forest quality-based assessment of the returning farmland to forest program at the community level in SW China. Forest Ecology and Management 461, 1-12.

Lin, B., Zhao, X.R., Zheng, Y., Qi, S., Liu, X.Z., 2017. Effect of grazing intensity on protozoan community, microbial biomass, and enzyme activity in an alpine meadow on the Tibetan Plateau. Journal of Soils and Sediments 17, 2752-2762.

Lin, D.S., Greenwood, P.F., George, S., Somerfield, P.J., Tibbett, M., 2011. The development of soil organic matter in restored biodiverse Jarrah forests of South-Western Australia as determined by ASE and GCMS. Environmental Science and Pollution Research International 18, 1070-1078.

Liu, J., Yang, Q., Siemann, E., Huang, W., Ding, J.Q., 2019. Latitudinal and altitudinal patterns of soil nematode communities under tallow tree (Triadica sebifera) in China. Plant Ecology 220, 965-976.

Liu, M.Y., Liu, M.M., Li, P., Yang, J.H., Wang, J., Chang, Q.R., 2020. Variations in soil organic carbon decompositions of different land use patterns on the tableland of Loess Plateau. Environmental Science and Pollution Research International 27, 4337-4352.

Liu, N., Ning, Y.Z., Ma, Z.X., He, J.J., 2008. Ecological effects of soil pollution by fluoride on soil protozoa. Journal of Northwest Normal University 44, 83-86.

Liu, T., Yang, L.H., Hu, Z.K., Xue, J.R., Lu, Y.Y., Chen, X.Y., Griffiths, B. S., Whalen, J.K., Liu, M.Q., 2020. Biochar exerts negative effects on soil fauna across multiple trophic levels in a cultivated acidic soil. Biology and Fertility of Soils 56, 597-606.

Lüftenegger, G., Foissner, W., Adam, H., 1985. R- and K-selection in soil ciliates: a field and experimental approach. Oecologia 66, 574 579.

Luo, X.T., Li, L.F., Wang, C.D., Bourland, W., Lin, X.F., Hu, X.Z., 2017. Morphologic and phylogenetic studies of two hypotrichous ciliates, with notes on morphogenesis in Gastrostyla steinii Engelmann, 1862 (Ciliophora, Hypotrichia). European Journal of Protistology 60, 119-133.

Mayzlish, E., Steiberger, Y., 2004. Effects of chemical inhibitors on soil protozoan dynamics in a desert ecosystem. Biology and Fertility of Soils $39,415-421$.

Mieczan, T., Adamczuk, M., Pogorzelec, M., 2017. Ciliates as restoration indicators in peatbogs -10 years of study. European Journal of Protistology 62, 11-23.
Mo, L.C., Liu, J.K., Chen, J.C., Xie, Y., 2020. Quantifying ecosystem services of dominate forests in the Beijing mountain area. Environmental Science and Pollution Research International 27, 27773-27785.

Ning, Y.Z., Du, H.F., Zou, T., Wang, H.J., 2011a. Toxic effects of entkaurane diterpenoids on soil ciliate communities. Acta Ecologica Sinica 31, 183-194.

Ning, Y.Z., Shen, Y.F., 1998a. Soil Protozoa in typical zones of China: I Faunal characteristics and distribution of species. Acta Ecologica Sinica 44, 5-9.

Ning, Y.Z., Shen, Y.F., 1998b. Soil Protozoa in typical zones of China: II Ecological study. Acta Ecologica Sinica 44, 271-276.

Ning, Y.Z., Wan, G.H., Yang, Y.G., Wu, W.N., Zhou, X.Y., Wang, Y.F., Liu, N., Cheng, X., Chen, L.Y., 2019. Community characteristics of soil ciliates in different modes of returning cropland to forest in Hui County, Gansu. Chinese Journal of Ecology 38, 1697-1706.

Ning, Y.Z., Wang, H.J., Yu, J.H., Du, H.F., 2011b. Response of the soil ciliate community to ecological restoration in Huajialing, Dingxi, Gansu. Zoological Research 32, 223-231.

Ning, Y.Z., Wang, T.T., Dong, W.H., Yang, Y.G., Yan, Z.J., 2017a. Community characteristics of spring soil ciliates in forestlands converted from cultivated lands in Qingcheng county of Gansu Province. Journal of Northwest Normal University 53, 88-93.

Ning, Y.Z., Wu, W.N., Du, H.F., Wang, H.J., 2016. Response of soil ciliate communities to ecological restoration after the implementation of the conversion of cropland to forest and grassland program: a case study of Platycladus orientalis forest. Acta Ecologica Sinica 36, 288-297.

Ning, Y.Z., Xu, F.R., Wang, T.T., 2020. Community characteristics of soil ciliates in forestlands converted from cultivated lands in Qingcheng County, Qingyang City. Ecology and Environmental Sciences 29, 506-515.

Ning, Y.Z., Yang, Y.G., Su, C., Chen, L.Y., Du, G.Z., 2017b. Effects of grazing on soil ciliate community in swamp meadow. Chinese Journal of Ecology 36, 1614-1621.

Ning, Y.Z., Yang, Y.Q., Dong, W.H., Zhang, H.R., Ma, J.Y., 2018. Response of soil ciliate community to ecological restoration of different return patterns. Acta Ecologica Sinica 38, 3628-3638.

Northwest Institute of Botany, Chinese Academy of Sciences, 1976. Flora Tsinlingensis. Beijing: Science Press.

Ouyang, Z.W., 2010. Study on Ecological Effects of Different Models of Converting Cropland to Forest and Grass in Karst Peak-clusterdepression Region. Dissertation, Hunan Agricultural University.

Pang, X.Y., Bao, W.K., 2011. Effect of substituting plantation species for native shrubs on the water-holding characteristics of the forest floor on the eastern Tibetan Plateau. Journal of Resources and Ecology 2, 217-224.

Piché, N., Kelting, D.L., 2015. Recovery of soil productivity with forest succession on abandoned agricultural land. Restoration Ecology 23, 645-654.

Sabais, A.C.W., Scheu, S., Eisenhauer, N., 2011. Plant species richness drives the density and diversity of Collembola in temperate grassland. Acta Oecologica 37, 195-202.

Schulz-Bohm, K., Geisen, S., Wubs, E.R.J., Song, C., Boer, W.D., Garbeva, P., 2016. The prey's scent-Volatile organic compound mediated interactions between soil bacteria and their protist 
predators. International Society for Microbial Ecology 16, 17517362.

Shang, W., Zhao, L., Wu, X.D., Li, Y.Q., Yue, G.Y., Zhao, Y.H., Qiao, Y. P., 2015. Soil organic matter fractions under different vegetation types in permafrost regions along the Qinghai-Tibet Highway, north of Kunlun Mountains, China. Journal of Mountain Science 12, 1010-1024.

Shao, C., Li, L.Q., Zhang, Q.Q., Song, W.B., Bergere, H., $2014 a$. Molecular phylogeny and ontogeny of a new ciliate genus, Paracladotricha salina n. g. n. sp. (Ciliophora, Hypotrichia). Journal of Eukaryotic Microbiology 64, 901-902.

Shao, C., Lu, X.T., Ma, H.G., 2014b. A general overview of the typical 18 frontal-ventral transverse cirri oxytrichidae s. I. genera (Ciliophora, Hypotrichia). Journal of Ocean University of China 14, 522-532.

Shen, Y.F., 1999. Protozoology. Science Press, Beijing.

Shen, Y.F., Zhang, Z.H., Gong, X.G., Gu, M.R., Shi, Z.X., Wei, Y.X., 1990. Modern biomonitoring techniques using freshwater microbiota. China Architecture \& Building Press, Beijing.

Song, W.B., Xu, K.D., Hu, X.Z., Lei, Y.L., Wei, J., Chen, Z.G., Shi, X.B., Wang, M., 1999. Progress in Protozoology. Qindao Ocean University Press, Qindao.

Vogel, H.J., Roth, K., 2001. Quantitative morphology and network representation of soil pore structure. Advances in Water Resources 24, 233-242.

Wan, N.F., Gu, X.J., Ji, X.Y., Jiang, J.X., Wu, J.H., Li, B., 2014 Ecological engineering of ground cover vegetation enhances the diversity and stability of peach orchard canopy arthropod communities. Ecological Engineering 70, 175-182.

Wanner, M., Birkhofer, K., Fischer, T., Shimizu, M., Shimano, S., Puppe, D., 2020. Soil testate amoebae and diatoms as bioindicators of an old heavy metal contaminated floodplain in Japan. Microbial Ecology 79, 123-133.

Xiong, W., Jousset, A., Guo, S., Karlsson, I., Zhao, Q.Y., Wu, H.S., Kowalchuk, G.A., Shen, Q.R., Li, R., Geisen, S., 2018. Soil protist communities form a dynamic hub in the soil microbiome. International Society for Microbial Ecology 18, 1751-7362.

Xue, G.Q., Liu, Q., Ren, X.F., Han, Y.Q., 2004. Determination of fifteen metal elements in Cynomorium songaricum by flame atomic absorption spectrophotometry (FAAS). Spectroscopy and Spectral Analysis 24, 1461-1463.

Yang, Z.B., Jin, H.X., Wang, G., 2010. An assessment of restoration success to forests planted for ecosystem restoration in loess plateau, Northwestern China. Environmental Science and Pollution Research International 164, 357-368.

Yeates, G.W., Bamforth, S.S., Ross, D.J., Tate, K.R., Sparling, G.P., 1991. Recolonization of methyl bromide sterilized soils under four different field conditions. Biology and Fertility of Soils 11, 181-189.

Zhang, C., Xue, S., Liu, G.B., Song, Z.L., 2011. A comparison of soil qualities of different revegetation types in the Loess Plateau, China. Plant and Soil 347, 163-178.

Zhang, L., Zhao, W., Zhang, R., Cao, H., Tan, W.F., 2018. Profile distribution of soil organic and inorganic carbon following revegetation on the Loess Plateau, China. Environmental Science and Pollution Research International 25, 30301-30314.

Zhang, M., Liang, W.J., Zhang, X.K., 2012. Soil nematode abundance and diversity in different forest types at Changbai mountain, China. Zoological Studies (Taipei) 51, 619-626.

Zhang, Z.L., Li, N., Xiao, J., Zhao, C.Z., Zou, T.T., Li, D.D., Liu, Q., Yin, H.J., 2018. Changes in plant nitrogen acquisition strategies during the restoration of spruce plantations on the eastern Tibetan Plateau, China. Soil Biology \& Biochemistry 119, 50-58.

Zhou, J.H., Hu, F., Jiao, J.G., Liu, M.Q., Li, H.X., 2012. Effects of bacterial-feeding nematodes and prometryne-degrading bacteria on the dissipation of prometryne in contaminated soil. Journal of Soils and Sediments 12, 576-585.

Zou, T., Shen, H.X., Ning, Y.Z., Ma, Z.X., 2009. Community characteristics of soil ciliates in the Mayan Forest Region of Xiaolong Mountains, Gansu. Chinese Journal of Zoology 44, 6473. 